\title{
STUDIES IN SERUM ELECTROLYTES
}

\section{Concentration of Electrolytes and Non-electrolytes in the Serum during Lobar PNeumonia}

By F. WILLIAM SUNDERMAN,1 J. H. AUSTIN AND J. G. CAMAC

(From the John Herr Musser Department of Research Medicine, University of Pennsylvania, Philadelphia)

(Received for publication June 3, 1926)

It has long been known that during the course of lobar pneumonia alterations in the chloride distribution in the blood and urine occur. During the stage of active infection there is a retention of chloride in the body as manifested by a decreased chloride elimination, whereas the blood in this period shows a hypochloremia. The present study was designed to follow the changes in the concentration in the serum of the electrolytes in general and of the non-electrolytes in patients with lobar pneumonia.

Hutchison (1898) studied the chloride metabolism in pneumonia and reviewed the literature up to 1898 . He showed that diminution in the urinary chlorides might occur in other febrile conditions but was not as constant as in pneumonia and did not occur in other pulmonary diseases. For this reason he believed that an examination of the chlorides was of value in differentiating pneumonia from empyema, pleurisy, et cetera.

Peabody (1913) studied the inorganic metabolism in pneumonia and reviewed the literature. In eight cases of pneumonia in which he studied the relation of chloride changes in the blood to changes in the urinary excretion he found that the decrease in the chloride excretion was associated with a lowered chloride concentration in the blood; and that at the time when excretion was increased, the blood chloride concentration was raised. His results also indicated a lowering of calcium and magnesium concentration of the blood during the stage of active infection.

${ }^{1}$ Robert M. Girvin Fellow in Research Medicine. 
McLean (1915), Maver and Schwartz (1916), Killian (1921), and Haden (1925) also have found a lowering of the chloride concentration in the blood serum in pneumonia. Maver and Schwartz (1916) observed that a diminished concentration of the plasma chlorides occurred at the height of the fever and that an increased concentration occurred immediately after the crisis. Peters, Bulger, Eisenman, and Lee (1926b) believe that factors in determining the low serum chloride in pneumonia are in some cases diminution in base and in others the presence of an unusual amount of organic acid.

Gerstenberger, Burhans, Smith, and Wetzel (1923) in studying the inorganic phosphorus and calcium concentration in the blood of nonrachitic children suffering with pneumonia found a reduction in both before the crisis. Jansen (1924) believes the calcium concentration is lowered during the febrile period and is increased in the afebrile.

Gram (1923) studied the freezing point depression on various pathological sera and found a decreased freezing point depression in nine determinations made during the active infection in lobar pneumonia. The average freezing point depression in his pneumonia serum observations was $0.534^{\circ} \mathrm{C}$. He made no post-critical determinations.

Considerable work is recorded in the literature on the blood gases in pneumonia. Peabody (1912) reviewed the literature on the carbon dioxide content of the blood. In his studies he concluded that there was a decrease for the most part in pneumonia but that "the diminution in the carbon dioxide in the blood bears no immediate relation to the temperature, as it may persist for some days after the patient is afebrile."

Stadie (1919) and Stadie and Van Slyke (1920) showed that neither the arterial nor venous carbon dioxide values were increased above the normal in pneumonia.

Meakins (1921) found the carbon dioxide content of arterial blood in four cases of lobar pneumonia decreased to from 42 to 44 volumes per cent (18.7 to 19.6 millimoles per liter). He believed that this decrease was the result of increased pulmonary ventilation.

Hastings, Neill, Morgan, and Binger (1924) studied the blood gases and reaction in sixteen cases of pneumonia. The carbon di- 
oxide content was within the normal area in twenty-four determinations; in three analyses the values were high and in three they were low.

Peters, Bulger, Eisenman, and Lee (1926) call attention to the fact that while the $\mathrm{CO}_{2}$ content in pneumonia cases in which the normal limits for afebrile patients, it is higher than that of patients with other febrile infections.

\section{MATERIAL AND METHODS}

Sixty-two specimens of blood from twenty-two patients with typical lobar pneumonia on the service of Dr. G. W. Norris at the Pennsylvania Hospital were examined.

Bleedings. Blood was drawn by vein puncture before breakfast and collected under oil. An eighteen caliber needle was introduced into the largest vein procurable at the elbow so that the blood would flow freely and venous stasis would be lessened. Peters, Bulger, Eisenman, and Lee (1926a) have shown that prolonged venous obstruction may alter the blood constituents. The blood was defibrinated under oil, centrifuged, and the serum removed under oil according to the technique of Austin and Gram (1924). Whenever possible, bleedings were made at intervals of two or three days on each patient before and after the crisis.

Freezing Point. In the determination of the freezing point the cryoscope of Burian and Drucker (1909) was employed. This instrument was checked at frequent intervals by making control readings of the depression in freezing point of solutions of known concentrations of sodium chloride. Before every two or three single determinations the zero reading of the Beckman thermometer was found by taking the freezing point of distilled water. Two or more readings were always made on separate samples of a given specimen of serum and the average of these readings was taken. In order to obtain an accuracy of plus or minus $0.005^{\circ} \mathrm{C}$., several precautions were deemed necessary: the cooling mixture was not lower than $-5^{\circ} \mathrm{C}$.; mechanical methods for stirring at a slow constant rate were utilized; and the convergence temperature was not more than $0.3^{\circ} \mathrm{C}$. below the freezing point obtained.

Conductivity. The conductivity estimations were made with the 
Christiansen (1922) ionometer as employed by Gram and Cullen (1923) using 110 volts D.C. This instrument was standardized daily by means of a known sodium chloride solution. Several readings of each specimen of serum were made at $20^{\circ} \mathrm{C}$. and expressed in sodium chloride equivalents, i.e., in terms of the concentration of sodium chloride in water required to give the same conductivity. In order to correct the conductivity for protein we used the correction of Gram and Cullen (1923) which is based upon the refractive index of serum against distilled water using the Abbe refractometer with a constant temperature of $17.5^{\circ} \mathrm{C}$.

$$
\begin{gathered}
C_{c}=C_{0} \frac{100}{100-(2.2 \times \mathrm{Pr})} \\
P_{\mathrm{r}}=\frac{R_{o}-R_{w}-0.0028}{0.00172}
\end{gathered}
$$

where $\quad C_{c}=$ corrected conductivity in $\mathrm{NaCl}$ equivalents.

$C_{o}=$ observed conductivity in $\mathrm{NaCl}$ equivalents.

$P_{r}=$ protein, grams per cent.

$R_{o}=$ refractive index of serum (Abbe refractometer).

$R_{w}=$ refractive index of water (Abbe refractometer $=$ 1.3332).

$0.0028=$ arbitrary correction for salts and non-electrolytes in serum.

$0.00172=$ Reiss' figure for the refractive index of 1 per cent protein solution.

Dry weight. As a means of checking the percentage of protein determined refractometrically, dry weights of the sera were obtained. Filter paper was folded into a weighing flask and dried at $110^{\circ} \mathrm{C}$. to a constant weight. One cubic centimeter of serum was dropped on the paper and weighed. The serum was then dried at $110^{\circ} \mathrm{C}$. and weighed two or more times until constant values were obtained.

The total base of fifty one samples of blood serum were analyzed according to the method of Stadie and Ross (1925). The chlorides were determined by means of the Van Slyke method (1923). The method of Folin (1922) was used in the determination of bloodurea nitrogen, sugar, creatinine, and in several instances non-protein nitrogen. $\mathrm{CO}_{2}$ analyses were made with Van Slyke's technique (1921). 
In the determination of the blood cholesterol the Myers and Wardell method was used (see Myers 1924).

\section{RESULTS}

We will present our results not only by the individual case tabulation (see table 2) but also by the aggregate of each type of determina-

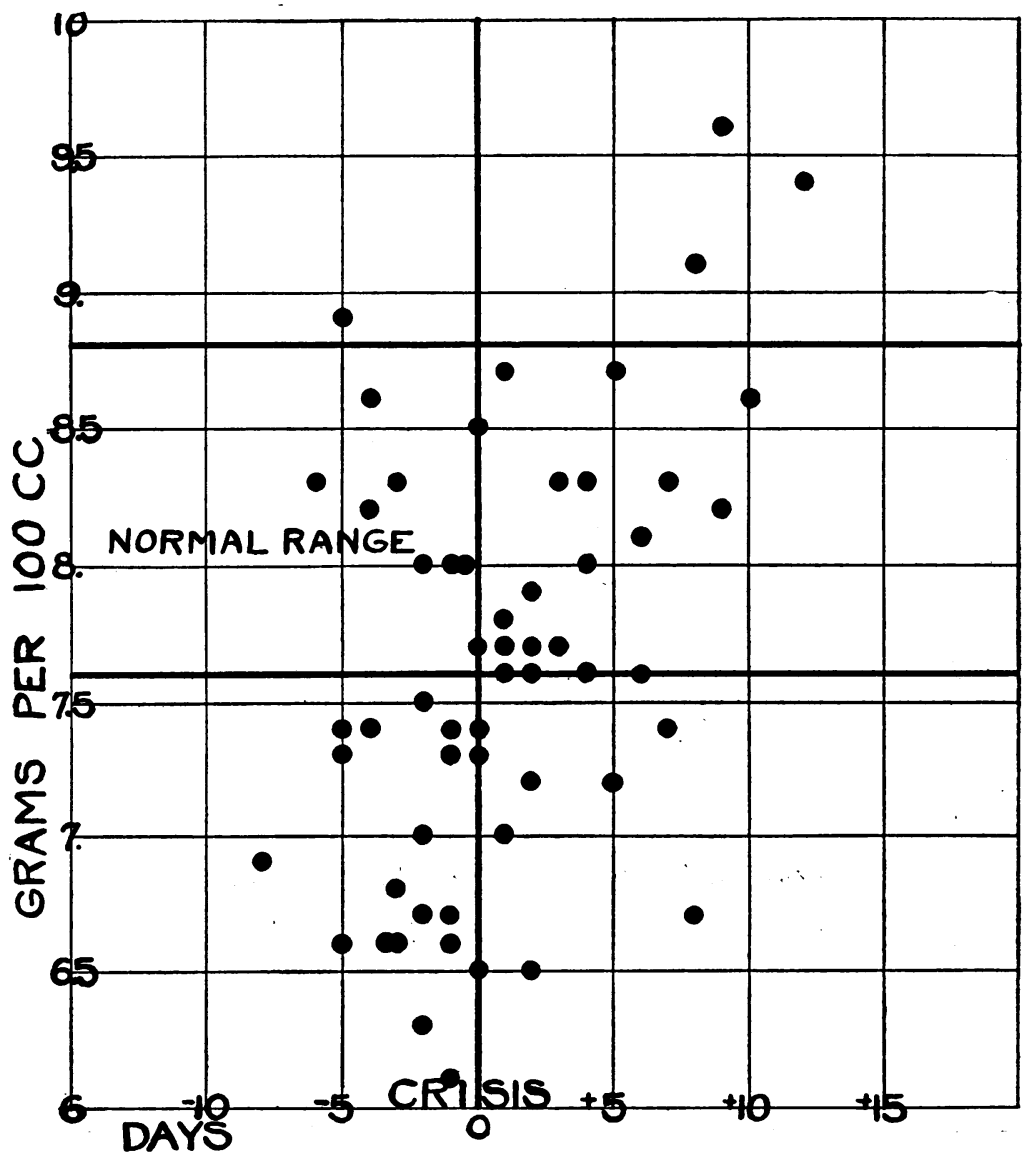

Fig. 1. Total Serum Protein (Refractometric)

tion as plotted before and after the crisis. The crisis is taken as the zero day; the time of the active infection or febrile period is designated minus days; and the time after the crisis is designated as plus days. 
Protein. If the normal values of protein in serum are taken as 7.6 to 8.8 per cent (Gram (1924) and table 1) it will be seen that the protein percentages apparently fluctuate considerably in the same individual. However, in the febrile period there is a tendency for the total serum protein to be lower than normal. This is followed about the time of the crisis by a tendency toward the normal range

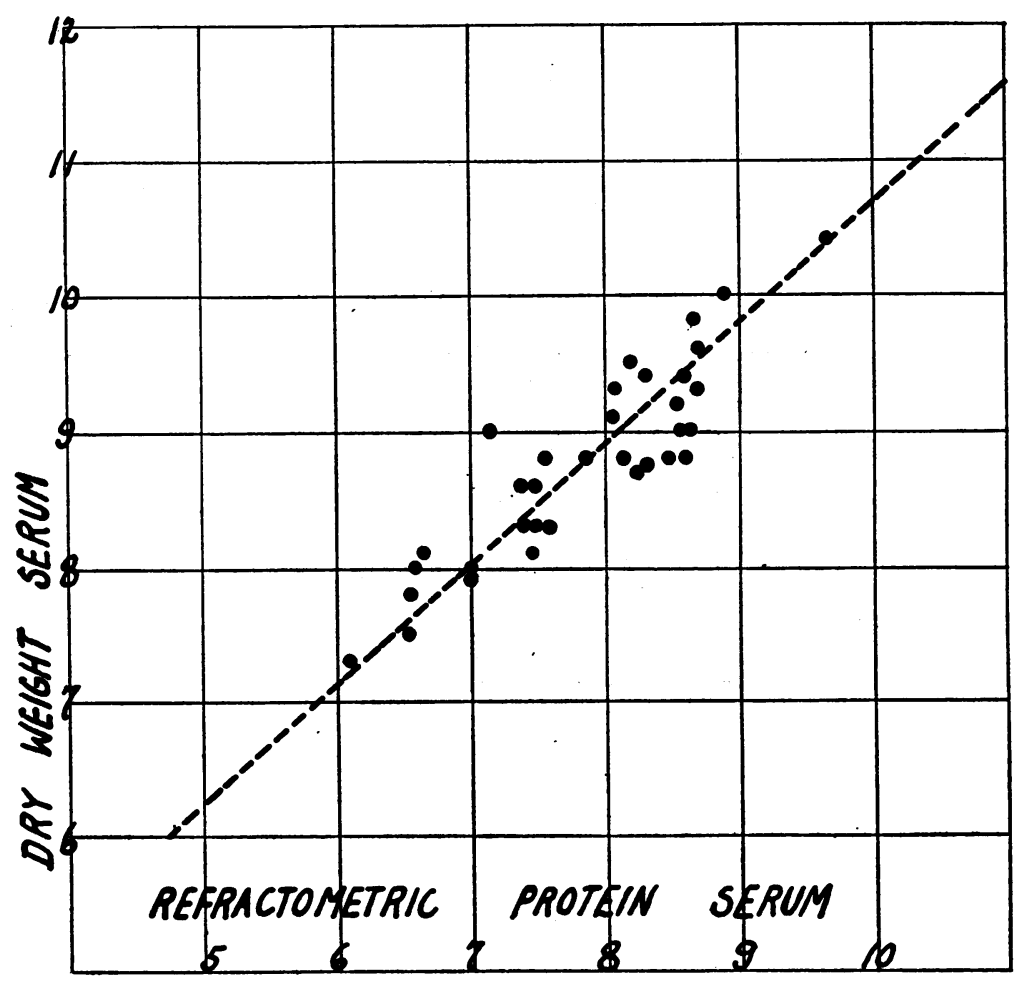

Fig. 2. Serum Dry Weight-Serum Protein

Expressed in grams per $100 \mathrm{cc}$.

or in several instances to above normal (fig. 1). Increase and decrease in protein was accompanied by and closely paralled respective increase and decrease in the dry weights. In our series the percentage of protein present as determined by means of the refractometer and Reiss' formula (Domarus, 1921) was approximately ninety per cent of the dry weight (fig. 2). 
$\mathrm{CO}_{2}$ content. $\mathrm{CO}_{2}$ content of the serum in our series remained for the most part within normal limits. In the period of hyperpyrexia seven analyses were below normal and in all of these there was hyperpnea (fig. 3).

Corrected conductivity. A range of corrected conductivity between (130 and 139) milliequivalents per liter has been taken as the normal (fig. 4, table 1 and Gram (1924)). Before the crisis the corrected con-

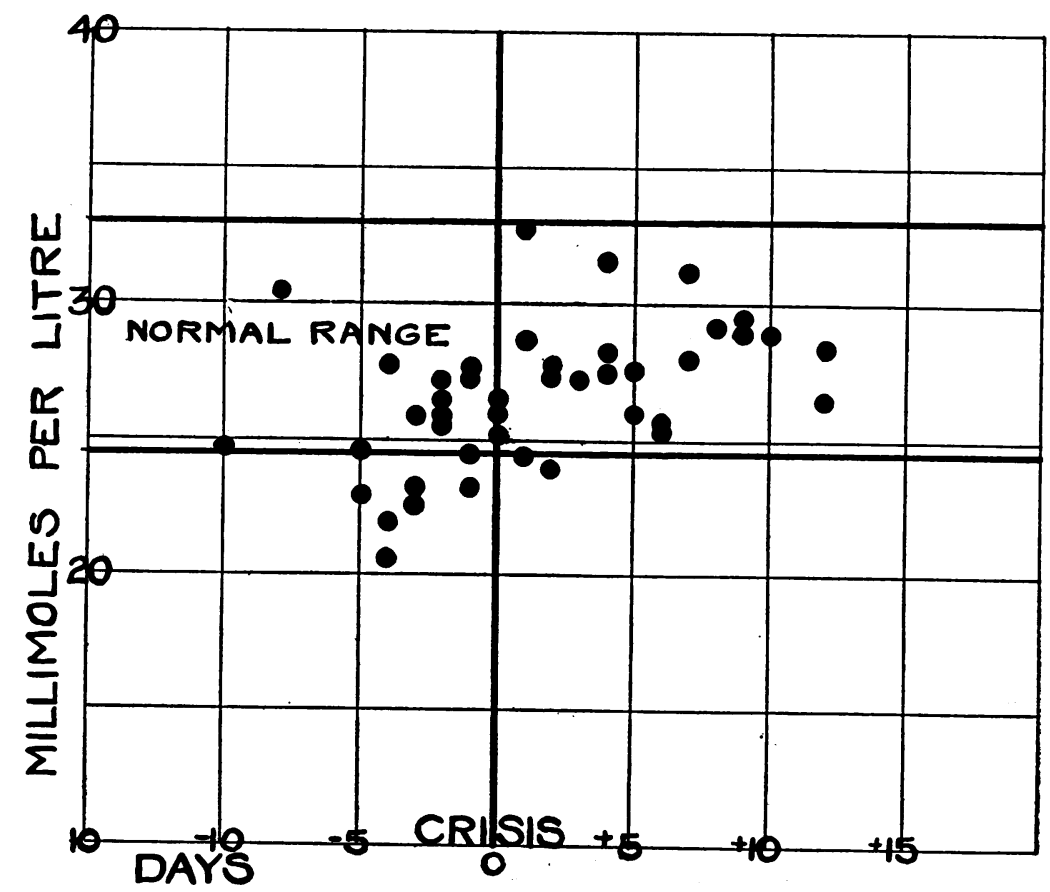

Fig. 3. $\mathrm{CO}_{2}$ IN SERUM

ductivity was consistently below the normal level. The decrease existed even in the earliest stages of the infection studied and in a given individual persisted immediately up to the crisis. With the exception of one case, in which the crisis occurred on the fifth day of the disease, the lowest conductivity was not observed earlier than the fifth day. In four out of eight cases which were followed for four days or more before the crisis there was a further fall in conductivity between the fifth and ninth days of the disease. Therefore, while 
conductivity was below normal in the earliest studies made, the fall may be progressive up to the ninth day. With the advent of the crisis, however, the conductivity rose toward the lower normal limit and sometimes continued to rise for several days after the crisis.

Total base. The analyses show a satisfactory correlation with the corrected conductivity values. If the base values be plotted as abscissae and the corrected conductivity values be plotted as ordi-

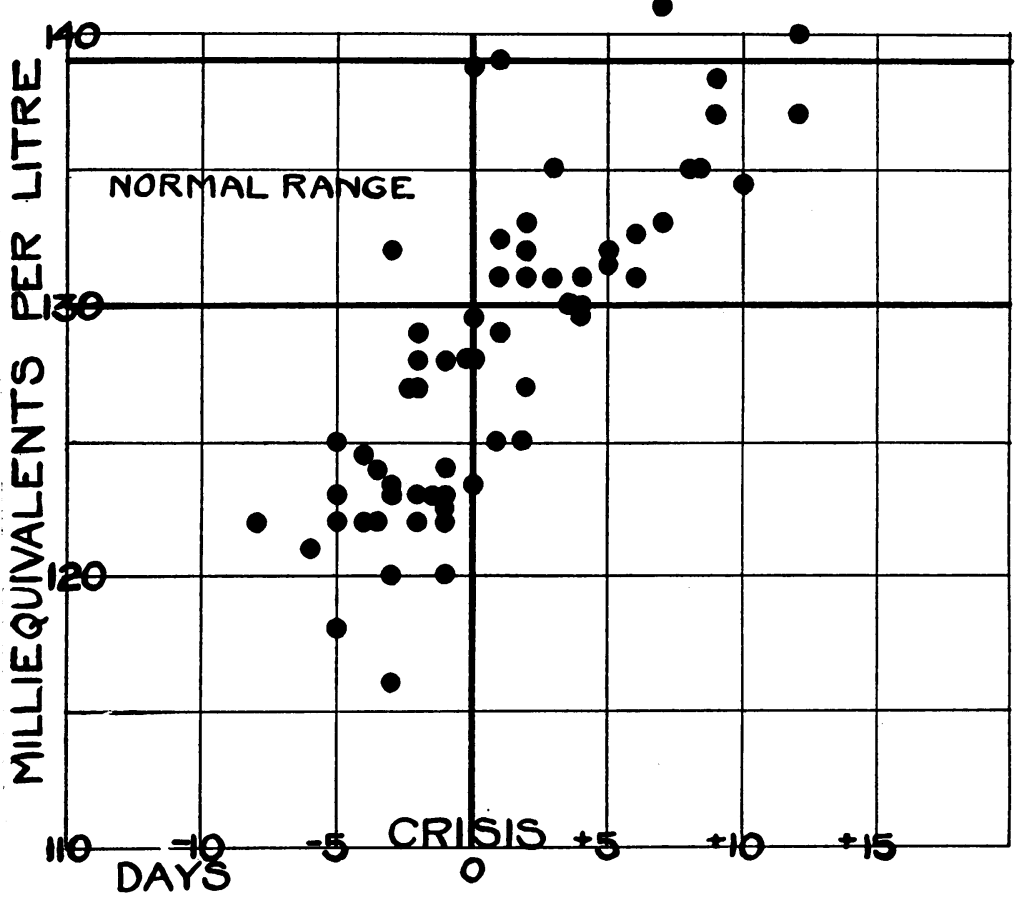

Fig. 4. Corrected Conductivity of Serum ( $\mathrm{NaCl}$ Equivalents)

nates it is shown on figure 5 that these values fall on a diagonal line and, using the factor of Gram and Cullen for obtaining corrected conductivity, it is approximately true that 1.13 times corrected conductivity equals total base (1.13 $C_{c}=$ base). Because of this linear relationship it is believed that the corrected conductivity may be used as a means of approximating the total base in serum where an accuracy within the limits of plus or minus 3 per cent is adequate. 
Since we have shown that the total serum base is approximately proportional to the conductivity, it is clear that the total base concentration of the serum was decreased throughout the entire precritical course of infection and tended to become normal after the crisis (fig. 6).

Chlorides. The chloride concentration in the blood serum during the course of lobar pneumonia was constantly below the normal level

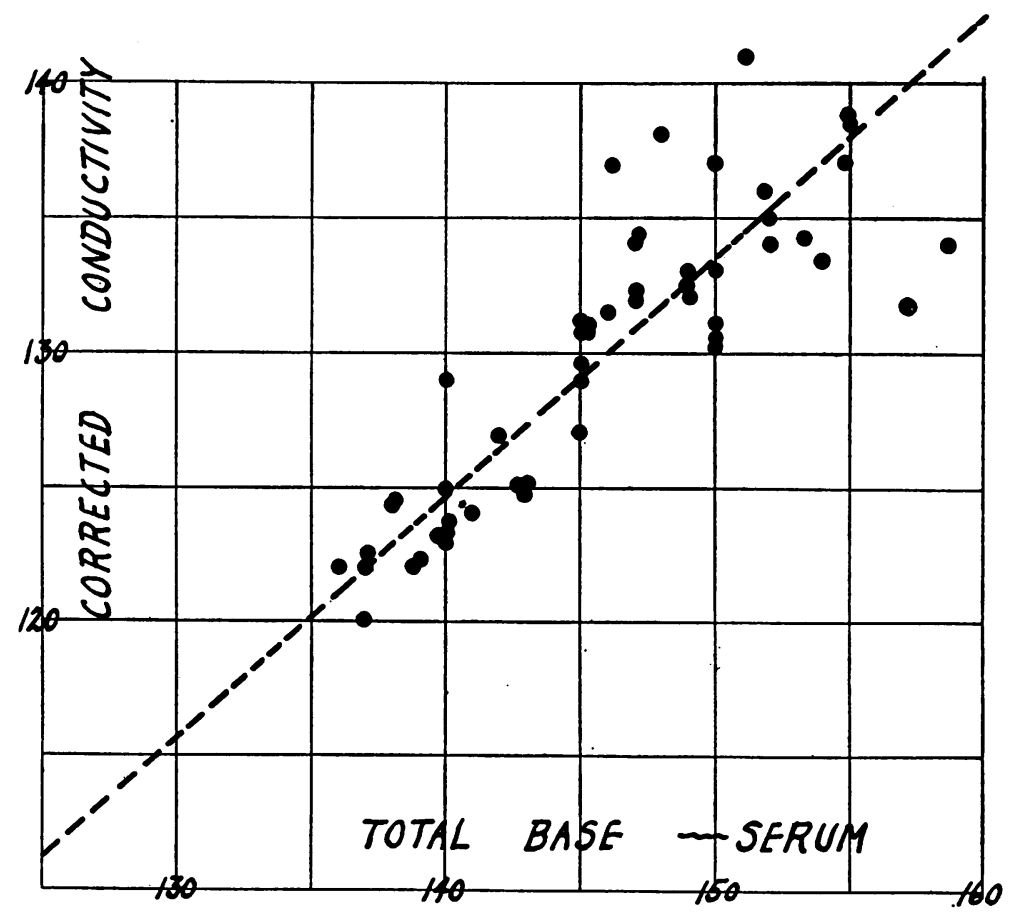

Fig. 5. Ratio of Corrected Conductivity of Serum to Total Serum Base (1.13 $C_{c}=$ base) (milliequivalents per liter)

(fig. 7). Following the crisis there was a tendency for a return to the lower normal range but in ten instances this was delayed. Haden (1925) has suggested a possible relation between the disturbance of body chlorides and the toxemia of lobar pneumonia. We have been unable to find any correlation clinically between those cases which showed an especially marked decrease of chlorides or the decrease persisting after the crisis and the severity of the toxemia. 
Freezing point. The depression in freezing point is dependent on the total os-molar concentration of solutes in the serum and is dependent therefore, not only on electrolytes, but on non-electrolytes as well. Normally the freezing point depression is between $0.55^{\circ}$ and $0.57^{\circ} \mathrm{C}$. (fig. 8 and table 1). In our series the freezing point depression was normal (two observations) or diminished in all of the

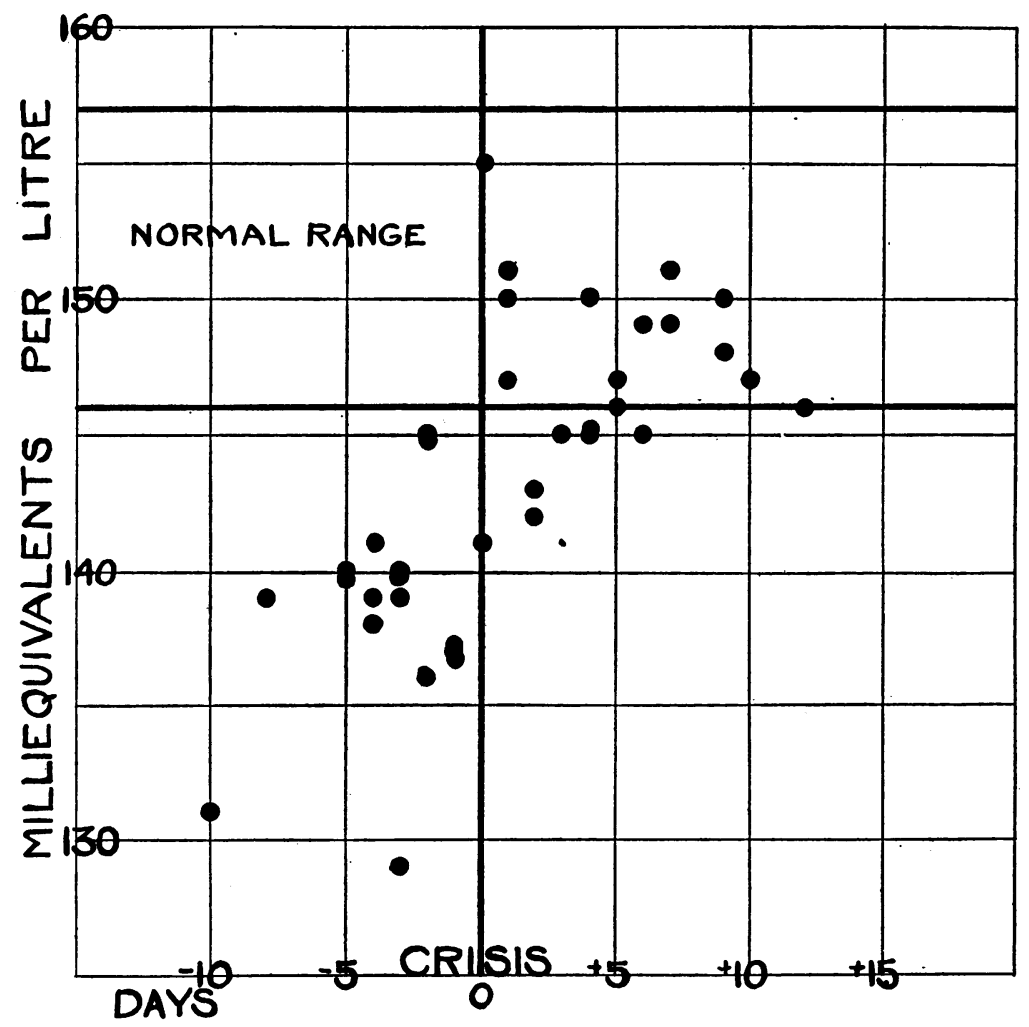

Fig. 6. TOtal BaSe IN SERUM

determinations during the stage of active infection excepting in one case, designated $G$ on the graph. In this case the blood urea nitrogen analyses on the various specimens were as follows:

$G_{1}=110 \mathrm{mgm}$. per $100 \mathrm{cc}$. blood.

$G_{2}=111 \mathrm{mgm}$. per $100 \mathrm{cc}$. blood.

$G_{3}=41 \mathrm{mgm}$. per $100 \mathrm{cc}$. blood. 
$G_{4}=$ not determined.

$G_{5}=15$ mgm. per $100 \mathrm{cc}$. blood.

While $110 \mathrm{mgm}$. of urea nitrogen per $100 \mathrm{cc}$. in $G_{1}$ in which the freezing point depression was $0.61^{\circ} \mathrm{C}$. would only account for an approximate increase of $0.02^{\circ}$ in the freezing point depression, the urea

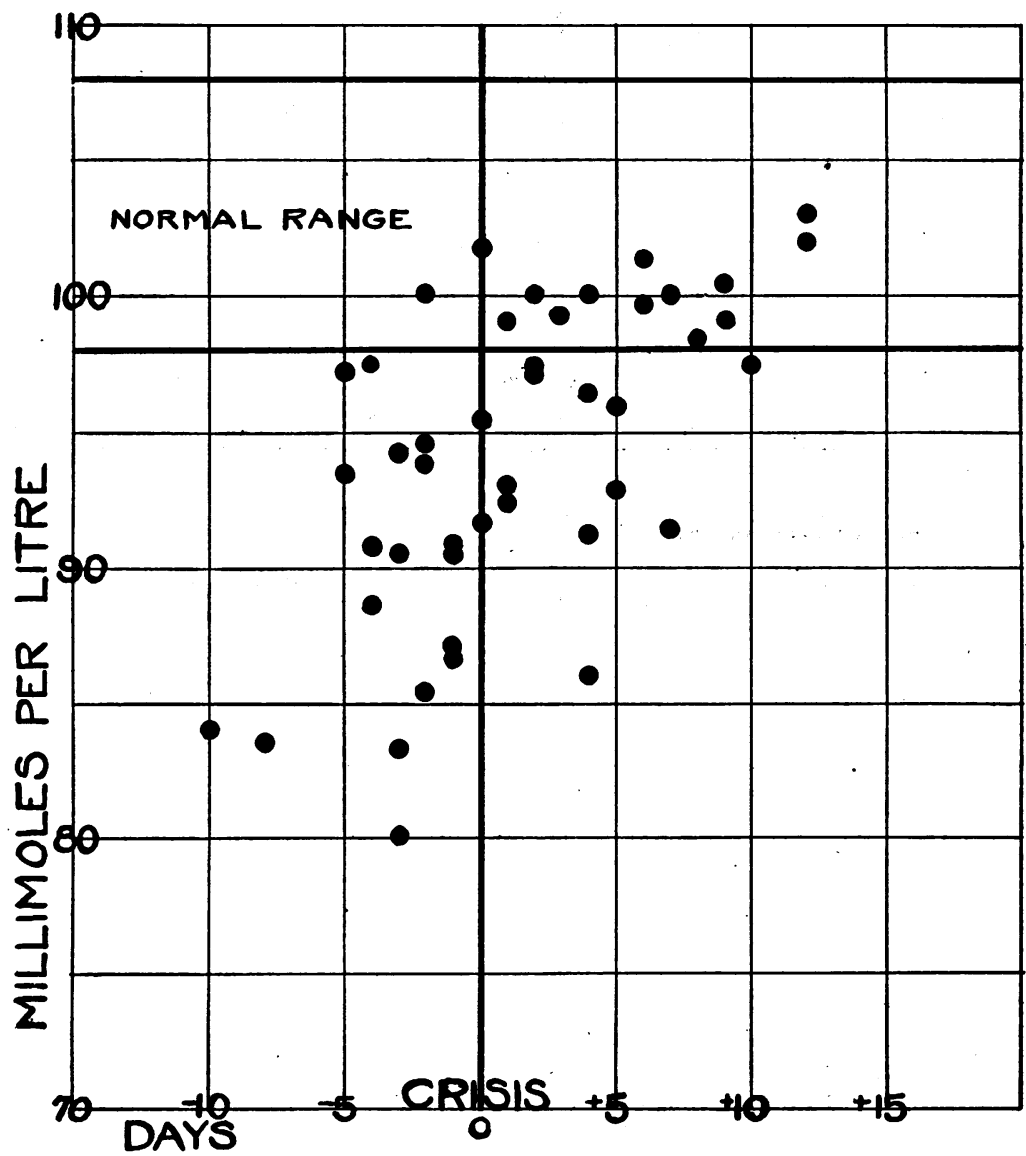

Fig. 7. Chloride in Serum

doubtless represents only a fraction of the non-electrolyte increase in this serum. With exception of this instance a diminished freezing point depression has consistently existed even in those observations. made very early in the infection-e.g., the second day of disease. As 
in the case of conductivity and base determinations the freezing point depressions of individual cases may show further diminution up to the ninth day. Immediately after the crisis the freezing point depressions for the most part were considerably higher than the

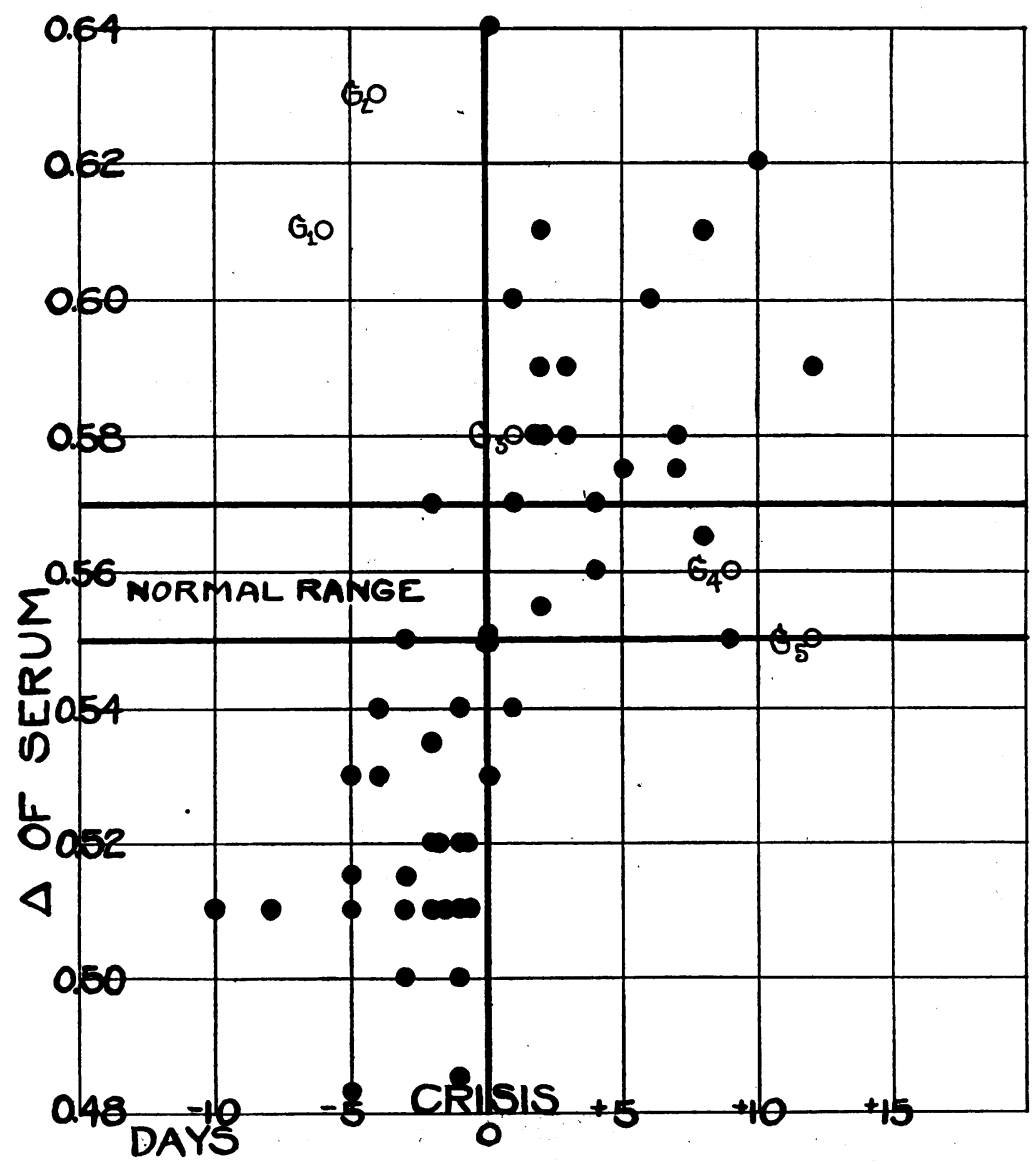

Fig. 8. Serum Freezing Point Depression ( $\Delta$ of serum)

$$
(G=\text { case } 16)
$$

normal level. That this increase is not entirely due to an increased electrolyte content is obvious when the ratio $\frac{\Delta}{C_{c}}$ is considered, where $\Delta$ represents the freezing point depression and $C_{c}$ the corrected conductivity in sodium chloride equivalents (fig. 9). 
In normal individuals the ratio $\frac{244 \Delta}{C_{0}}$ varied from 0.98 to 1.03 . This ratio remains constant when changes in the freezing point depression are due entirely to changes in the electrolyte content. Hence the ratio may serve as an index of the concentration of non-electrolytes in the serum. When $\frac{244 \Delta}{C_{0}}$ was calculated from our data, during

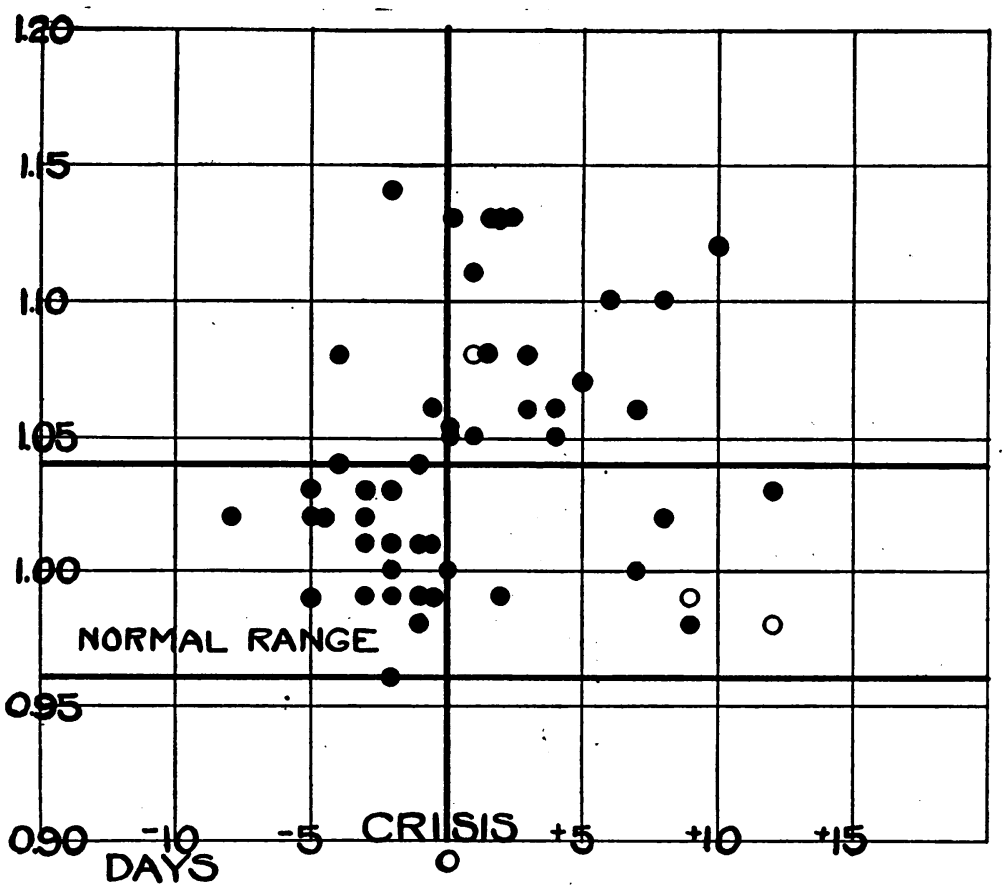

Fig. 9. Ratio of Freezing Point Depression to Corrected Conductivity

$$
244 \frac{\text { Freezing point depression }}{\text { Corrected conductivity }}
$$

O refers to case "G" under freezing point depression or to case 16 on the tables

the active infection it was for the most part within the normal limits. After the crisis, however, the ratio was increased beyond the normal range especially during the first few days following the crisis, with the exception of one observation. Thus we conclude that the decreased depression in freezing point during the active infection can be accounted for by the decrease in electrolytes, whereas after the 
crisis the increase in freezing point depression is caused in part by the presence of abnormally high concentrations of non-electrolytes.

Protein-corrected conductivity ratio. The refractometric protein measurements were made primarily to correct the conductivity values according to the formula of Gram and Cullen. However, with the data collected and several possible relations of the protein

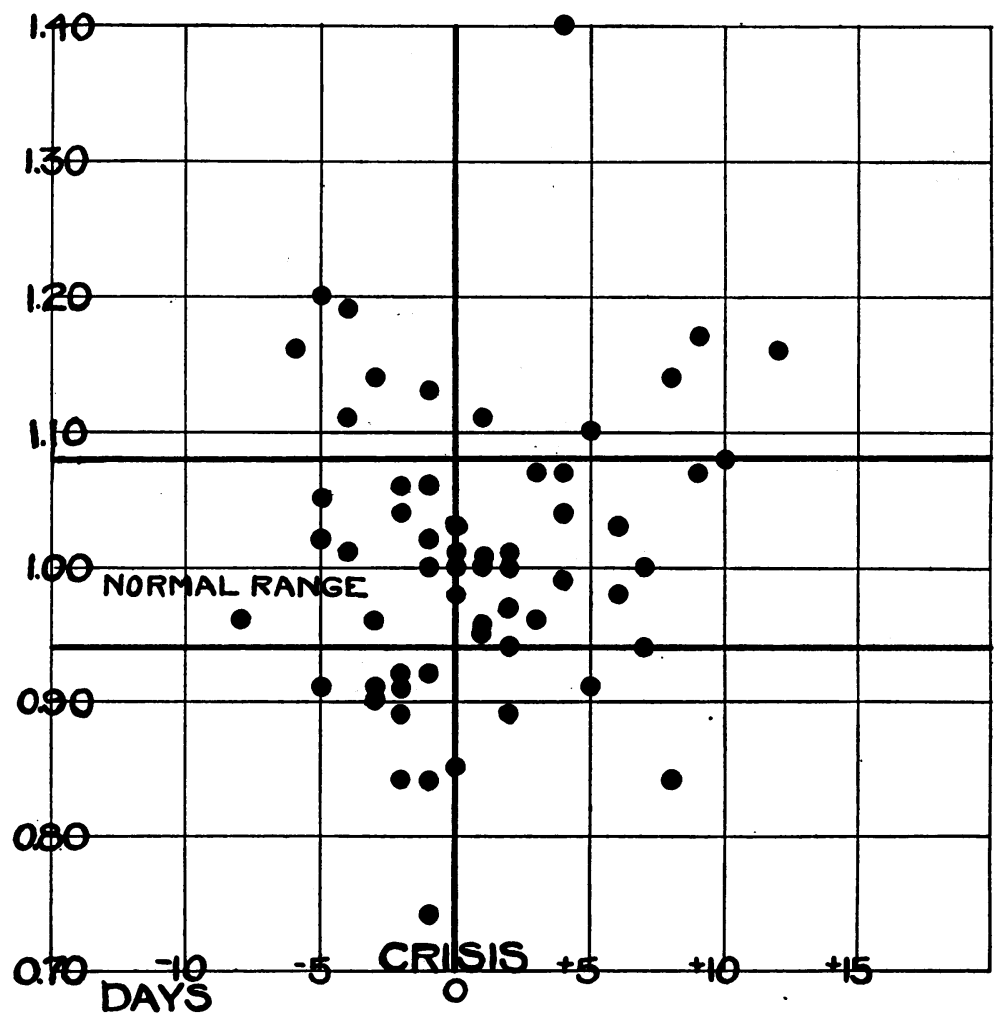

Fig. 10. Ratio of Protein to Corrected Conductivity

$$
16.9 \frac{\text { Protein }}{\text { Corrected Conductivity }}
$$

concentration to our results suggesting themselves, we regret that the protein determinations were not made by more accurate methods, thus avoiding the known discrepancies with refractometric measurements. While no conclusions are drawn from individual ratios of protein concentration and corrected conductivity equivalents, nevertheless, the trend of this ratio we are confident is significant. 
It is shown on figures 1 and 4 that protein and corrected conductivity values tend to be lower during the precritical course and return to the normal range during convalescence. The percentage decrease in both approximates 10 per cent. Thus if the ratio of protein to corrected conductivity be considered, it is shown on figure 10 that the ratio fluctuates about an average value which remains approxi-

TABLE 1

Normal subjects

\begin{tabular}{|c|c|c|c|c|c|c|c|}
\hline Subject & $\begin{array}{c}\text { Serum } \\
\text { freezing } \\
\text { point } \\
\text { depression }\end{array}$ & $\begin{array}{c}\text { Serum } \\
\text { corrected } \\
\text { conduc- } \\
\text { tivity }\end{array}$ & $\begin{array}{c}\text { Serum } \\
\text { protein } \\
\text { (refracto- } \\
\text { metric) }\end{array}$ & $\begin{array}{c}\text { Serum tota } \\
\text { base }\end{array}$ & $\begin{array}{l}\text { Serum chlo- } \\
\text { ride }\end{array}$ & $244 \frac{\Delta}{C_{c}}$ & $\begin{array}{l}\text { Pro- } \\
16.9 \frac{\text { tein }}{C_{c}}\end{array}$ \\
\hline & ${ }^{\circ} \mathrm{C}$. & $\begin{array}{c}m E q \text {. per } \\
\text { liter }\end{array}$ & 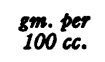 & $\begin{array}{l}m E q \text {.per } \\
\text { liter }\end{array}$ & $\begin{array}{c}m E q . \text { per } \\
\text { liter }\end{array}$ & & \\
\hline F.W.S....... & 0.555 & 136 & 7.7 & & & 1.00 & 0.96 \\
\hline$C \ldots \ldots \ldots \ldots$ & 0.55 & 134 & 7.7 & 152 & & 1.00 & 0.97 \\
\hline $\mathbf{R}, \ldots \ldots \ldots \ldots$ & 0.56 & 133 & 8.3 & 154 & & 1.03 & 1.05 \\
\hline $\mathbf{P}, \ldots, \ldots, \ldots, \ldots, \ldots$ & 0.57 & & 8.1 & 150 & & & \\
\hline w. $\ldots \ldots, \ldots \ldots \ldots$ & 0.55 & & 8.7 & 150 & & 1.03 & \\
\hline Pe.......... & 0.555 & 131 & 7.6 & & & 1.03 & 0.98 \\
\hline s. $\ldots \ldots, \ldots, \ldots$, & & 134 & 7.8 & 157.6 & 103.7 & & 0.98 \\
\hline Sel. $\ldots \ldots \ldots \ldots \ldots \ldots$ & & 136 & 8.4 & 151.7 & 101.2 & & 1.04 \\
\hline $\operatorname{Rei} \ldots \ldots \ldots \ldots \ldots$ & & 137 & 8.0 & 154.8 & 105.3 & & 0.98 \\
\hline Rob......... & & 134 & 8.6 & 153.4 & 103.5 & & 1.08 \\
\hline C. C.S... & & & & & 105.8 & & \\
\hline H. W.S.... & & & & & 106.4 & & \\
\hline C.F.... & & & & & 104.3 & & \\
\hline H. T....... & & & & & 101.4 & & \\
\hline Maximum. & 0.57 & 137 & 8.7 & 157.6 & 106.4 & & \\
\hline Minimum........ & 0.55 & 131 & 7.6 & 150 & 101.2 & & \\
\hline Average......... & 0.557 & 133 & 8.09 & 154.7 & 103.95 & & \\
\hline Number of deter- & & & & & & & \\
\hline minations..... & 6 & 8 & 10 & 8 & 8 & & \\
\hline
\end{tabular}

mately the same throughout the entire infection. In normal individ-

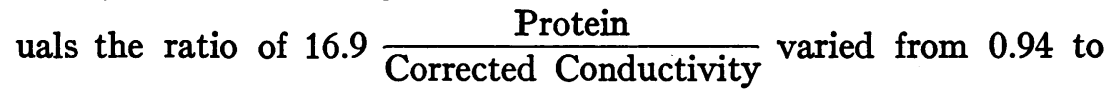
1.08. During the stage of active infection this ratio tends to fluctuate more than normally and perhaps more than after the crisis. 


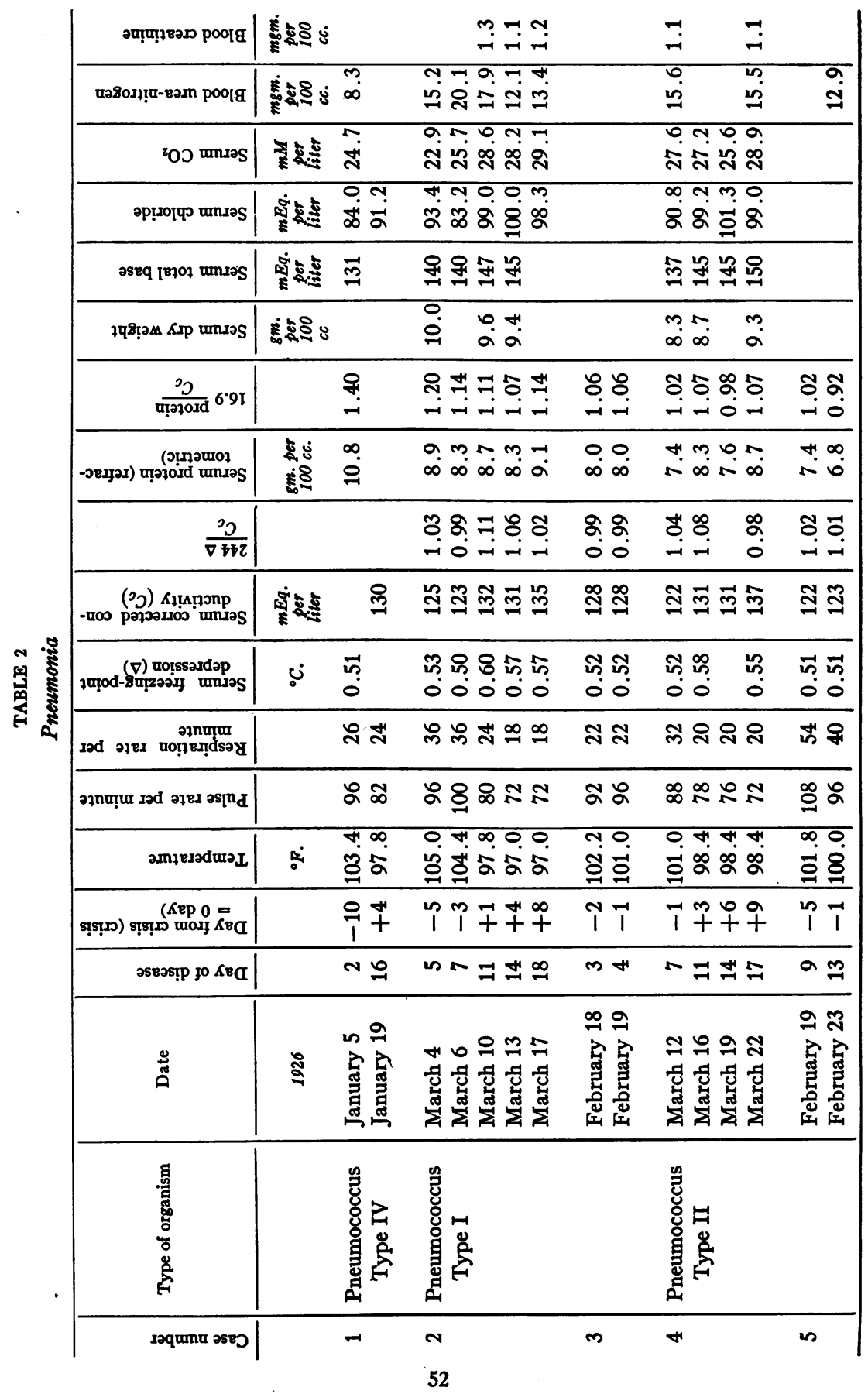




\begin{tabular}{|c|c|c|c|c|c|c|c|}
\hline & in & $\stackrel{+}{ت}$ & $\underset{-1}{-1}$ & $\stackrel{m}{-i}$ & & & \\
\hline 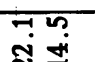 & कृ & $\tilde{n}_{i}$ & $9 \stackrel{n}{n}$ & 0 & & & ra \\
\hline$\frac{n}{4-4}$ & $\infty$ & 70 & $4 \pi$ & N & 6 & $=$ & $\frac{d-a}{n-n}$ \\
\hline จิ & นุ่ & 8 ก & ด्रลล & జ్ల & i & มุ & ข \\
\hline म० & T & $\infty \infty$ & फ 0 ० काल & $\circ$ & m. & + & ? \\
\hline$\widehat{a} \infty$ & s & పૂる & 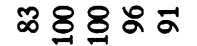 & $\approx$ & $\hat{a}$ & ฉ & \$ే \\
\hline 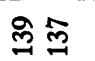 & 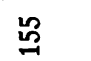 & 正年 & 孚急 号 & in & $\dddot{7}$ & & 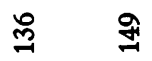 \\
\hline$\ddot{a} a$ & $\underset{\infty}{\infty}$ & $\ddot{a}$ & 紫 & $\vec{\infty}$ & $\stackrel{0}{\infty}$ & & $\overbrace{\infty}^{\infty}$ \\
\hline 굼 & $\stackrel{\text { o̊ }}{i}$ & $8 \stackrel{8}{9}$ & 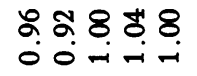 & $\stackrel{\circ}{0}$ & 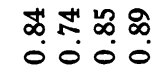 & పై & 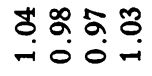 \\
\hline $\begin{array}{ll}0 & 0 \\
\infty & 0\end{array}$ & $\underset{\infty}{\infty}$ & $\stackrel{m}{n}$ & ดे유 & $\stackrel{0}{i}$ & 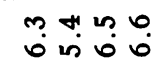 & $\mathfrak{i}$ & $\stackrel{1}{n}$ \\
\hline \&̊ & $\stackrel{m}{-}$ & & ธ్ర & 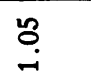 & 809 & 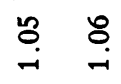 & 편 \\
\hline ส్ ฐ్తి & gे & జ్త & స్తి స్తి & $\stackrel{乛}{乛}$ & స్తి & స్తి & 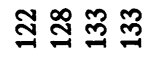 \\
\hline ț & ț & & 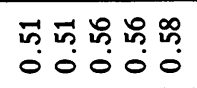 & : & 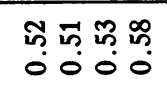 & $\begin{array}{ll}\stackrel{n}{n} & 0 \\
0 & 0 \\
0\end{array}$ & 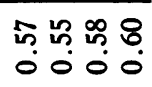 \\
\hline 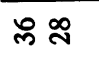 & $\$$ & q & ゚ ボポ。 & ల్ & భ నొ నొ ని & సేరి శి & ł శి శ శ \\
\hline ఫ્తిః & $\tilde{-}$ & 28 & : & $\stackrel{\circ}{\circ}$ & ฌ ホ & ฌా & శ్తి \\
\hline $\begin{array}{l}0.0 \\
\dot{i} \\
\text { s. }\end{array}$ & ס्: & $\begin{array}{l}0.0 \\
8 \%\end{array}$ & 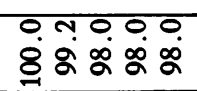 & $\begin{array}{l}0 \\
\infty\end{array}$ & 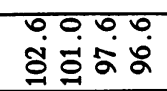 & 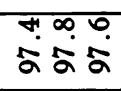 & 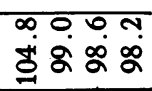 \\
\hline$\vec{i}$ & 0 & 0 年 & 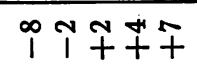 & $F$ & กิ゚ & $0 \mp+$ & $\mathfrak{1}^{\circ}+{ }^{\circ}$ \\
\hline oa & 우 & -9 & シే శి & $\Rightarrow$ & $-\infty a=$ & $\infty 0 \infty$ & $\Rightarrow m 29$ \\
\hline 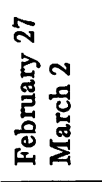 & 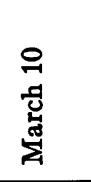 & 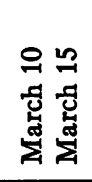 & 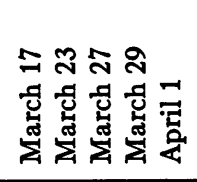 & 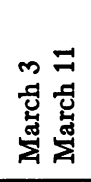 & 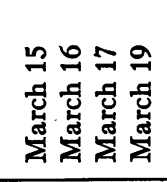 & 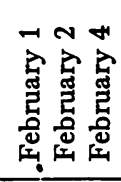 & 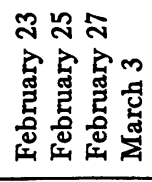 \\
\hline 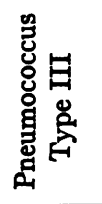 & 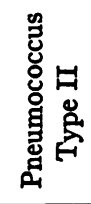 & & 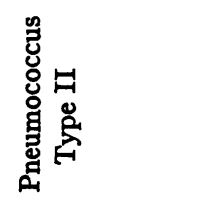 & 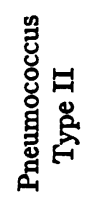 & 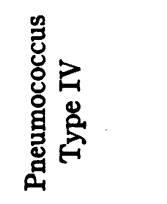 & 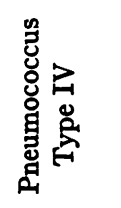 & 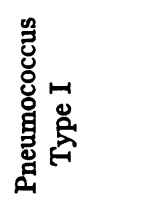 \\
\hline ○ & - & $\infty$ & $a$ & 웅 & $=$ & $\approx$ & $m$ \\
\hline
\end{tabular}




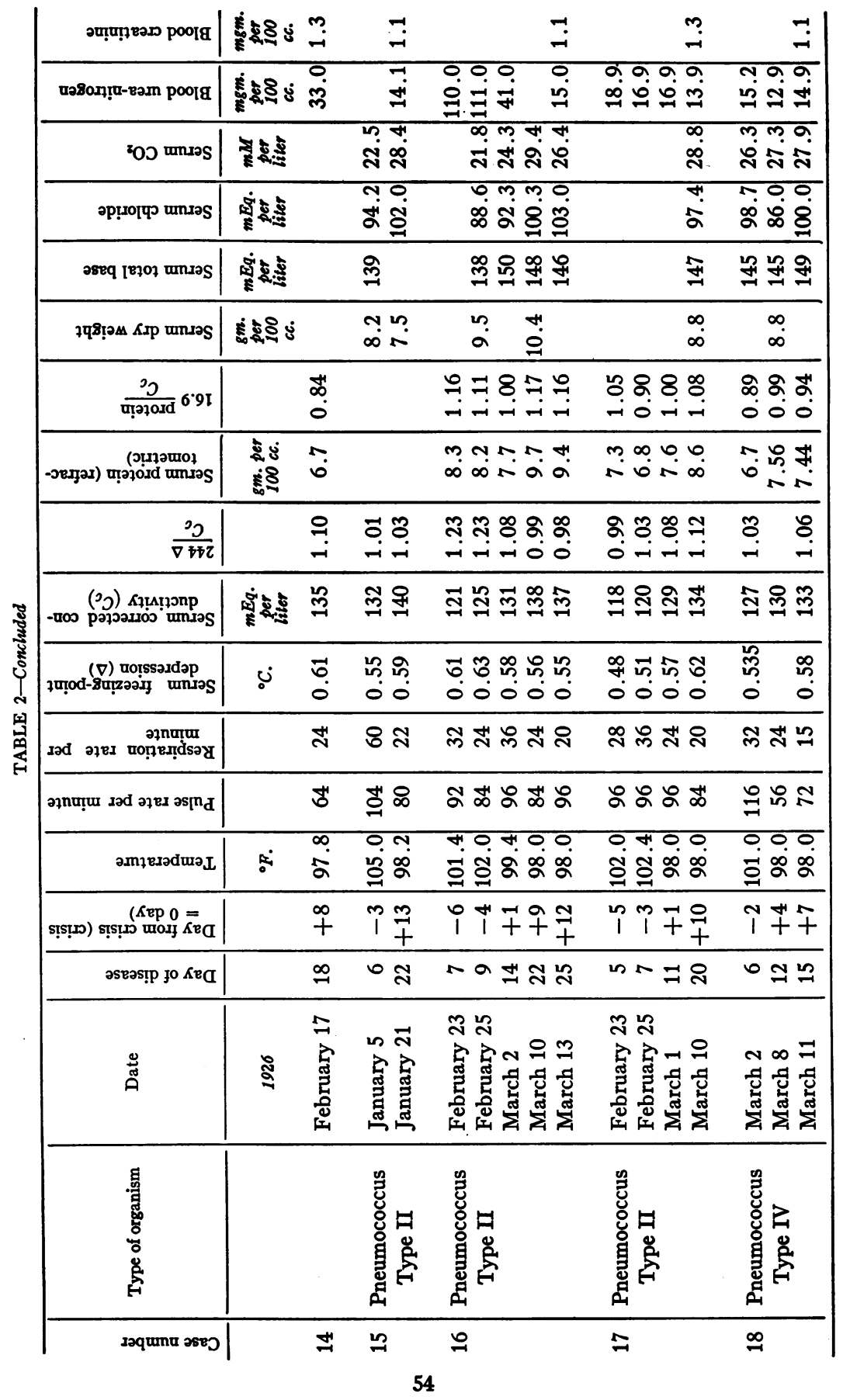




\begin{tabular}{|c|c|c|c|}
\hline$\stackrel{m}{-i}$ & 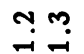 & & $\stackrel{-}{~}$ \\
\hline 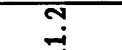 & חִ & & $\overline{0}$ \\
\hline-7 & तू & & $\Rightarrow$ न \\
\hline ה & ล่ & & 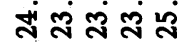 \\
\hline \multirow{4}{*}{$\underset{\infty}{-1}$} & กm & $\circ$ & $\because n$ గ \\
\hline & $8 ळ$ & ஓ & ลัஃタลส \\
\hline & $\exists$ & స్తి & 웜웜웜웜 \\
\hline & $\stackrel{\infty}{0} \underset{\infty}{\infty} \stackrel{\infty}{\infty}$ & & 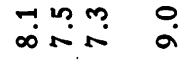 \\
\hline 8 & वे. & o̊ & 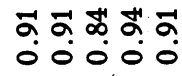 \\
\hline$\stackrel{m}{a}$ & 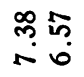 & ? & 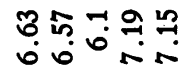 \\
\hline 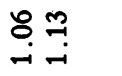 & تِ & & 엄 \\
\hline సี & 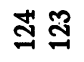 & $\rightleftarrows$ & శ్తి ఇָత్త స్తు \\
\hline 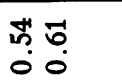 & 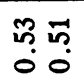 & & 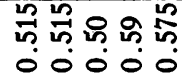 \\
\hline ల్లి జి & స్ల న్ల & $\$$ & హె గి นำ ని ని \\
\hline$\stackrel{8}{\circ}$ & 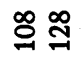 & ఫ్తి & ఫ్తి ర్తి సిన \\
\hline $\begin{array}{l}0.0 \\
8 \dot{8} \\
8\end{array}$ & $\begin{array}{l}0.0 \\
0.0 \\
0\end{array}$ & ت্: & 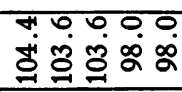 \\
\hline †ิ & Ti & i & 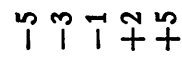 \\
\hline$\infty=$ & ins & $a$ & $m-a \approx n$ \\
\hline 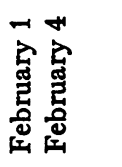 & 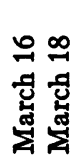 & 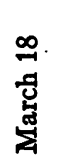 & 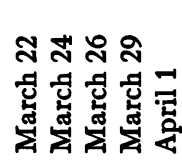 \\
\hline 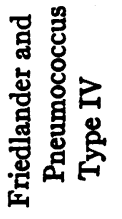 & 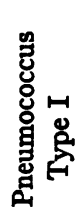 & 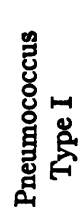 & 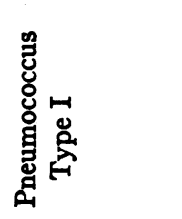 \\
\hline 2 & ని & $\vec{A}$ & สี \\
\hline
\end{tabular}




\section{DISCUSSION}

In considering the fate of the electrolytes during the precritical course in pneumonia, the question is raised whether the decrease in electrolyte concentration in the serum is due to a process of simple dilution.

It can occur that the total amount of serum protein remains constant while the water content of the serum changes. Under these conditions change in serum protein concentration is an index of gain or loss of serum water. Such gain or loss of water is often accompanied by an associated gain or loss of salts; this is not always the case, however. Hamilton, Barbour and Loomis (1925) have made use of the $\frac{\text { protein }}{\text { salt }}$ ratio in their studies on heat regulation and water exchange and have found conditions in which this ratio is not significantly altered when the water content of the serum is increased. In our studies the protein concentration and the corrected conductivity both showed approximately the same percentage decrease during the precritical period with the maintenance of a constant mean $\frac{\text { protein }}{\text { corrected conductivity }}$ ratio. This might suggest that the decrease in concentration of electrolytes and protein was caused by a process of simple dilution. That this increase cannot be explained as incident to mere water retention in the body tissues, as a whole, is obvious when the known degree of sodium chloride retention in pneumonia is considered.

Hutchison (1898) pointed out that in the precritical period of pneumonia a retention of as much as 12 grams of sodium chloride is not unusual. If it be supposed that this is retained in a concentration equal to that found in lymph and serum, there would be necessary a simultaneous retention of about 20 liters of water. It is clear that this is not the case especially when the weight during pneumonia is considered. Leyden as early as 1869 showed that there was a progressive loss of weight in the precritical period in pneumonia patients while still greater loss occurred with the crisis.

The decrease in electrolyte concentration in the serum cannot therefore be considered a part of simple dilution of the body tissues, 
as a whole, with water, but it will be necessary to have studies upon blood volume in pneumonia to determine whether or not the fall in electrolyte and protein concentration in the serum is due to simple dilution of the serum with water, while the retained chloride and perhaps also water are accumulated in the other tissues of the body. Such blood volume studies we have now in progress.

In spite of the loss of weight in pneumonia there is evidence in the literature that the ratio of water to dry substance is increased in certain of the other tissues of the body as well as in the serum. Hutchison (1898) observed a slight increase in the water content of muscle and Maver and Schwartz (1916) found in all of the pneumonia cases studied, moderate degrees of edema in the subcutaneous tissues by the use of the Schade elastometer. The latter observers also noted that the elasticity curve did not return to the normal immediately after the crisis as did the chloride concentration of the blood.

Furthermore, according to Hutchison (1898), the sputum, exudates, muscles, and viscera are all richer in chloride to total dry substance than normally. Peabody (1913) confirmed the widespread distribution of retained chloride in pneumonia. and since no particular storage place was found, he believed that the retained inorganic substances are "spread diffusely throughout the body."

It may be possible that retention of both water and chlorides occur in the general tissues of the body, while in the serum possibly water alone is retained.

The precise nature of the non-electrolyte increase following the crisis has not been definitely determined. Cohn (1922) in an analysis of the blood of fifty-five patients with pneumonia found an increase in the non-protein nitrogen in 87 per cent of his cases. The increased values appear to have had no relation to temperature changes. Killian (1922) found that the non-protein nitrogen was increased after the crisis. There was an increase after the crisis in two cases which Haden (1925) reported. The maximum increase in his cases, however, would only account for about onefifteenth of the post-critical increase in non-electrolytes which is indicated by our data. Our results in regard to the nature of the non-electrolyte increase are not sufficient to draw conclusions.

In the two cases in which the blood cholesterol was determined 
before and after the crisis, there was a post-critical hypercholesterolemia and in this our results would confirm the work of Kipp (1920). (The cholesterol results are recorded in protocols 1 and 15.)

\section{SUMMARY}

The percentage of protein in the serum as determined by means of the refractometer and Reiss' constant was approximately 90 per cent of the dry weight. The protein values tended to be below the normal during the febrile period and rise to the normal following the crisis.

$\mathrm{CO}_{2}$ content remained approximately within the normal range throughout the disease.

The corrected conductivity was consistently below the normal during the precritical period and following the crisis rose to the normal limits.

The corrected conductivity obtained with the factor of Gram and Cullen and expressed in milliequivalents of $\mathrm{NaCl}$ was related to the total base within the limits of 3 per cent as follows: $1.13 C_{c}=$ total base.

The total base concentration in the serum was decreased during the active infection and tended to become normal after the crisis.

The chlorides were below normal during the precritical course and tended to reach the normal more slowly than the total electrolytes following the crisis.

The ratio $\frac{\Delta}{C_{c}}$ is within the normal limits during the active infection and is increased especially during the first five days following the crisis.

During the active infection in lobar pneumonia there was a decrease in the electrolytes in the serum and a proportional decrease in the freezing point depression. After the crisis the electrolytes returned to the normal range, whereas the freezing point depression was increased beyond the normal limits. This increase after the crisis must therefore be due to abnormally high amounts of nonelectrolytes in the serum.

The ratio of protein to corrected conductivity fluctuates about an average value which remains approximately the same throughout the entire infection. 


\section{PROTOCOLS}

Case 1. (No.276.) Colored, male, age 37, laborer. On admission, the second day of the disease, the patient had consolidation of the right lower lobe. He appeared extremely toxic and was irrational most of the time during the active infection. The blood culture was sterile: sputum yielded a Type IV pneumococcus. The right upper lobe became involved on the tenth dav of the infection. The crisis occurred on the twelfth day. Convalescence was uneventful. Wassermann was strongly positive before and after the crisis. The blood cholesterol on the second day of the disease was $123 \mathrm{mgm}$. per $100 \mathrm{cc}$; on the sixteenth day, 192 mgm. per $100 \mathrm{cc}$.

Case 2. (No. 1220.) Colored, male, age 19, laborer. The patient was admitted to the hospital on the fourth day of the disease with consolidation of the left lower lobe. He was wildly delirious and required restraint. The leucocyte counts on the fourth and fifth days of the disease were 37,000 and 36,400 respectively, the polymorphonuclears being 94 per cent. The blood culture was negative; sputum contained a Type I pneumococcus.

Case 3. (No. 1009.) Colored, male, age 48, laborer. The patient was admitted with incipient delirium tremens and lobar pneumonia confined to the right lower lobe. The temperature returned to the normal by crisis on the fifth day of the disease. Convalescence was uneventful.

Case 4. (No. 1365.) American, male, age 46, printer. Five days before admission the patient noticed a dull pain in left lower chest, a brown tinged expectoration, and fever. At the time of admission he appeared moderately toxic and cyanotic. The sputum showed a Type II pneumococcus. The leucocyte count was 32,200 .

Case 5. (No. 1015.) Italian, male, age 35, stone mason. On admission the patient had a dusky cyanosis of the face, herpes on the lips and nose, and a low, muttering delirium. The respirations were rapid (fifty-four per minute), restricted and shallow. The physical signs of consolidation were present over both the right and left lower lobes. The leucocytes were 10,200 on admission with 90 per cent polymorphonuclears. Four days later the leucocyte count was 24,600. The abdomen was greatly distended and polypnea was marked throughout the entire active infection.

Case 6. (No. 1146.) Colored, male, age 18, student. On admission the pneumonia was localized to the right lower lobe. The blood culture was negative: sputum yielded a Type III pneumococcus. The leucocyte count was 26,400 with 87 per cent polymorphonuclears. The patient, in addition, had a mitral stenosis which had followed rheumatic fever in childhood. On the ninth day the patient had a pseudo-crisis which was followed on the tenth day by the true crisis. 
Case 7. (No. 1287.) American, male, age 46, policeman. The patient was admitted to the hospital on March the sixth with consolidation of entire right lung. The leucocyte count was 17,800 with polymorphonuclears 86 per cent. On March the eighth the blood urea nitrogen was $20.2 \mathrm{mgm}$. and the creatinine $2.8 \mathrm{mgm}$. per $100 \mathrm{cc}$. The patient was extremely cyanotic, unconscious, and breathed rapidly with considerable effort. The abdomen was greatly distended. Phlebotomy was done on March the ninth and $820 \mathrm{cc}$. of blood were removed. The patient was given hypodermoclysis of normal salt solution in $1000 \mathrm{cc}$. quantities on two occasions on March 10. The patient died on March 10 at a time which was interpreted as being the crisis.

Case 8. (No. 1274.) Hebrew, male, age 10, student. Consolidation of the lung was limited to the right upper lobe. The leucocyte count on admission was 30,000 . Crisis occurred on the seventh day. Convalescence was uneventful.

Case 9. (No. 1370.) German, male, age 26, laborer. The patient was admitted to the ward with consolidation of the right lower lobe. On the following day, the eighth day of the disease, it was noted that the left lower lobe also was involved. The sputum contained a Type II pneumococcus. During the period of active infection the patient was wildly delirious. The urine showed a heavy cloud of albumen, granular casts, and red blood cells. On two occasions sugar was present in the urine (March 10-0.35 per cent). The temperature reached normal by lysis on the twenty-second day. The Wassermann reaction was very strongly positive before and after the temperature became normal.

Case 10. (No. 1172.) Italian, male, age 44, laborer. The patient entered the hospital with a right lower lobar pneumonia. The sputum yielded a Type II pneumococcus. The leucocytes on admission were 31,000 with 92 per cent polymorphonuclears. The crisis occurred on the tenth day. On the fifteenth day the patient developed a fever and had a leucocyte count of 21,600. Physical signs of a right interlobar empyema were found and the patient was transferred to the surgical service for thoracotomy.

Case 11. (No. 879.) American, male, age 25, laborer. On admission the patient suffered from excruciating pains in left lower chest over which area pleural frictions were heard. The chest was strapped but without much relief. Blood culture was sterile: the sputum yielded a Type IV pneumococcus.

Case 12. (No.702.) White, male, age 39, laborer. The patient was admitted to the hospital on the third day of the disease with consolidation of right lower lobe. The sputum yielded a Type IV pneumococcus and a hemolytic streptococcus. The crisis occurred on the fifth day. 
Case 13. (No. 1076.) Colored, male, age 39, laborer. On admission, the tenth day of the disease, the patient had pneumonia of the right lower lobe. The leucocyte count was 19,000 wbich rose to 30,200 the following day with 92 per cent polymorphonuclears. The patient appeared very toxic and was moderately jaundiced. The blood culture and sputum both yielded a Type I pneumococcus. The urine contained a heavy cloud of albumen with many dark granular casts. The crisis occurred on the thirteenth day. Convalescence was uneventful.

Case 14. (No. 789.) Italian, male, age 36, laborer. The pneumonia was confined to the right lower lobe. The patient was delirious, cyanotic and appeared extremely toxic. The leucocyte counts ranged between 16,000 and 20,600 during the precritical course. Following the crisis, on the tenth day of the disease, the patient developed a gluteal pneumococcus abscess which was incised and drained.

Case 15. (No. 252.) Italian, male, age 15, student. The patient was admitted to the hospital on the third day of the disease with a consolidation of the left lower lobe. The respirations were very rapid (60 per minute), and voluntarily restricted due to intense pleural pain. The sputum contained a Type II pneumococcus. The leucocyte count was 17,800 with 84 per cent polymorphonuclears. The crisis occurred on the ninth day. The blood cholesterol on the sixth day of the disease was $137 \mathrm{mgm}$. per $100 \mathrm{cc}$.; on the twenty-second day, $173 \mathrm{mgm}$. per $100 \mathrm{cc}$.

Case 16. (No. 1095.) Colored, male, age 35, laborer. On admission the sixth day of the disease, the patient had a consolidation of the right upper and middle lobes. The leucocyte count was 26,800 with 95 per cent polymorphonuclears. Three days later, the ninth day, the right lower lobe became involved at which time his leucocyte count was 26,600 . The patient was very weak and markedly jaundiced. The sputum contained a Type II pneumococcus. On the twelfth day of the disease there was an attempted crisis, however, the true crisis did not occur until the thirteenth day. The urine contained a trace of albumin with occasional light granular casts. The blood urea nitrogen was greatly increased during the precritical period and returned to the normal during convalescence. The Wassermann reaction was strongly positive before and after the crisis.

Case 17. (No. 1060.) Egyptian, male, 31, painter. The patient had a pneumonia of the right lower lobe. On admission the leucocyte count was 8,200 which rose three days later to 21,400 . The patient was mentally below the normal. He gave a history of previous antiluetic treatment and his Wassermann reaction before and after the crisis was very strongly positive. The crisis occurred on the tenth day.

Case 18. (No. 1162.) Colored, male, age 23, laborer. The consolidation was limited to the left lower lobe. The leucocyte count was 30,500 with 95 per cent 
polymorphonuclears. Sputum contained a Type IV pneumococcus. The crisis occurred on the eighth day of the disease. In addition to the pneumonia, the patient had a luetic aortitis and an acute arthritis. Wassermann reaction was very strongly positive.

Case 19. (No.689.) American, male, age 38, laborer. The patient entered the hospital with a lobar pneumonia of the left base and an acute pleurisy. He appeared toxic and cyanotic. The sputum contained a Friedlander's bacillus and a Type IV pneumococcus. The temperature reached the normal level on the ninth day. On the eleventh day the temperature was elevated to $100^{\circ} \mathrm{F}$. and the leucocyte count was 19,400. At this time, physical signs of an interlobar empyema were obtained. A thoractomy was done and the pus drained. The patient died on the thirty-sixth day of the disease.

At autopsy both lungs were riddled with recent multiple abscesses. A dark field examination of the abscess walls proved the tissue to be literally alive with spirochetes of the Vincent type and fusiform bacilli.

Case 20. (No. 1413.) Colored, male, age 34, laborer. The patient had a left lower lobar pneumonia. The blood culture and sputum both yielded Type I pneumococcus. On two occasions the patient was given $100 \mathrm{cc}$. of Type I antipneumococcus serum intravenously. Death occurred on the ninth day of the disease, at a time interpreted as the crisis. The diagnosis was confirmed at autopsy.

Case 21. (No. 1400.) Colored, female, age 30, housewife. On admission the third day of the disease the patient had consolidation of the right lower and middle lobes. The leucocyte count was 40,200 at this time. On the ninth day of the disease the left lower lobe was involved and the leucocyte count rose to 48,800 . The sputum contained a Type I pneumococcus. Crisis occurred on the twelfth day.

Case 22. Spaniard, age 24, sailor. The patient was admitted on the fifth day of the disease with consolidation of left lower lobe. His respirations were very rapid and voluntarily restricted on account of intense pleural pains. Loud pleural frictions were heard in left axilla. The leucocyte count was 23,200 with the polymorphonuclears 90 per cent. The sputum yielded a Type I pneumococcus; blood culture was sterile. Crisis occurred on the tenth day.

\section{BIBLIOGRAPHY}

Austin, J. H., and Gram, H. C.: Jour. Biol. Chem., 1924, lix, 535. The Effect of Ether Added in Vitro on the Carbon Dioxide and Chloride Distribution between Cells and Serum.

Burian, R., and Drucker, K.: Centr. Physiol., 1909-10, xxiii, 772. Gefrierpunktsmessungen an kleinen Flussigkeitsmengen. 
Christiansen, J.: Wien. Klin. Woch., 1922, xxxv, 461. Eine einfache klinische Methode zur Leitfahigkeitsbestimmung.

Cohn, E.: Deut. Med. Woch., 1922, xlviii, 226. Ueber das Verhalten des Reststickstoffs im Blute bei krupposer Pneumonie, Scharlach, Masern und Diphtherie.

Domarus, A: Methodik der Blutuntersuchung mit einem Anhang; Zytodiagnostiche Technik. Berlin, 1921, p. 211.

Folin, O.: Lab. Manual of Biological Chemistry. 1922 (Appleton).

Gerstenberger, H. J., Burhans, C. W., Smith, D. N., and Wetzel, N. C.: Amer. Jour. Dis. Child., 1923, xxvi, 329. The Blood Serum Content of Inorganic Phosphorus and Calcium in Pneumonia.

Gram, H. C.: Jour. Biol. Chem., 1923, lvi, 593. Observations on Regulation of Osmotic Pressure (Conductivity, Chlorides, Freezing Point, and Proteins of Serum).

Gram, H. C.: Amer. Jour. Med. Sci., 1924, clxviii, 511. Composition and Physical Properties of Normal Human Blood; A Compilation of Values from the Literature.

Gram, H. C., and Cullen, G. E.: Jour: Biol. Chem., 1923, lvii, 477. The Accuracy of the "Ionometric" Method and of the Protein Correction in Measuring Serum Conductivity.

Haden, R. L.: Jour. Lab. and Clin. Med., 1925, x, 337. The Relation of the Chloride Metabolism to the Toxemia of Lobar Pneumonia.

Hamilton, W. F., Barbour, H. G., and Loomis, N. M.: Jour. Physiol., 1925, lix, 306. Heat Regulation and Water Exchange. VI. The Mobilization of Water and Salt in Warm Environments.

Hastings, A. B., Neill, J. M., Morgan, H. J., and Binger, C. A. L.: Jour. Clin. Invest., 1924, i, 25. Blood Reaction and Blood Gases in Pneumonia.

Hutchison, R.: Jour. Path. and Bact., 1898, v, 406. Chloride Metabolism in Pneumonia and Acute Fevers.

Jansen, W. H.: Deut. Arch. fur Klin. Med., 1924, cxliv, 14. Kalkstudien am Menschen. Der Kalkgehalt des menschlichen Blutes unter pathologischen Verhaltnissen.

Killian, J. A.: Proc. N. Y. Path. Soc., New Series, 1921-1922, xxii, 72. Chemical Changes in the Blood in Pneumonia.

Kipp, H. A.: Jour. Biol. Chem., 1920, xliv, 215. Variation in Cholesterol Content of the Serum in Pneumonia.

Leyden, E.: Arch. fur Klin. Med., 1869, v, 273. Untersuchungen über das Fieber.

Maver, M. E., and Schwartz, A. B.: Arch. Int. Med., 1916, xvii, 459. Studies of Edema in Pneumonia.

McLean, F. C.: Jour. Exp. Med., 1915, xxii, 366. The Numerical Laws Governing the Rate of Excretion of Urea and Chlorides in Man.

Meakins, J.: Jour. Path. and Bact., 1921, xxiv, 79. Observations on the Gases 
in Human Arterial Blood in Certain Pathological Pulmonary Conditions, and Their Treatment with Oxygen.

Myers, Victor C.: Practical Chemical Analysis of Blood. 1924, Mosby.

Peabody, F. W.: Jour. Exp. Med., 1912, xvi, 701. The Carbon Dioxide Content of the Blood in Pneumonia.

Peabody, F. W.: Jour. Exp. Med., 1913, xvii, 71. Studies of the Inorganic Metabolism in Pneumonia with Especial Reference to Calcium and Magnesium.

Peters, J. P., Bulger, H. A., Eisenman, A. J. and Lee, C.: Jour. Biol. Chem., 1926a, lxvii, 175. Total Acid-Base Equilibrium of Plasma in Health and Disease. IV. The Effects of Stasis, Exercise, Hyperpnea, and Anoxemia; and the Causes of Tetany.

Peters, J. P., Bulger, H. A., Eisenman, A. J., and Lee, C.: Jour. Biol. Chem., 1926b, lxvii, 219. Total Acid-Base Equilibrium of Plasma in Health and Disease. V. Miscellaneous Pathologic Conditions.

Schade, H.: Zeitsch. f. exper. Path. u. Therap., 1912, xi, 369. Untersuchungen zur Organfunction des Bindegewebes.

Stadie, W. C.: Jour. Exp. Med., 1919, xxx, 215. The Oxygen of the Arterial and Venous Blood in Pneumonia and Its Relation to Cyanosis.

Stadie, W. C., and Van Slyke, D. D.: Jour. Biol. Chem., 1920, xli, 191. Studies of Acidosis. XV. Carbon Dioxide Content and Capacity in Arterial and Venous Blood Plasma.

Stadie, W. C., and Ross, E. C.: Jour. Biol. Chem., 1925, lxv, 735. A Micro Method for the Determination of Base in Blood and Serum and Other Biological Materials.

Van Slyke, D. D. and Stadie, W. C.: Jour. Biol. Chem., 1921, xlix, 1. The Determination of the Gases of the Blood.

Van Slyke, D. D.: Jour. Biol. Chem., 1923, lviii, 523. The Determination of Chlorides in Blood and Tissues. 